\title{
Inhibition of Listeria and Staphylococcus aureus by Bovicin HC5 and Nisin Combination in Milk
}

\author{
Natan de Jesus Pimentel-Filho ${ }^{1}$, Hilário Cuquetto Mantovani ${ }^{1}$, Francisco Diez-Gonzalez ${ }^{2} \&$ \\ Maria Cristina Dantas Vanetti ${ }^{1}$ \\ ${ }^{1}$ Departamento de Microbiologia, Universidade Federal de Viçosa, Viçosa, Brazil \\ ${ }^{2}$ Department of Food Science and Nutrition, University of Minnesota, Saint Paul, USA \\ Correspondence: Maria Cristina Dantas Vanetti, Departamento de Microbiologia, Universidade Federal de Viçosa, \\ Viçosa MG 36570-000, Brazil. Tel: 55-31-3899-2954. E-mail: mvanetti@ufv.br
}

Received: May 14, 2013 Accepted: June 13, 2013 Online Published: July 15, 2013

doi:10.5539/jas.v5n8p188 URL: http://dx.doi.org/10.5539/jas.v5n8p188

\begin{abstract}
The aim of this work was to evaluate the effect of the bacteriocins bovicin HC5 and nisin against Listeria and Staphylococcus aureus in synthetic media and in milk. Growth of Listeria monocytogenes, Listeria innocua and S. aureus was carried out at $37^{\circ} \mathrm{C}$ in tryptic soy broth (TSB) and in ultra-high temperature whole milk containing bovicin HC5 and nisin added either individually or in combination. Concentrations above $100 \mathrm{AU} \mathrm{ml}^{-1}$ of bovicin $\mathrm{HC} 5$ or $50 \mathrm{AU} \mathrm{ml}^{-1}$ of nisin inhibited the growth of Listeria species in TSB. Bacteriocins at concentrations of at least $50 \mathrm{AU} \mathrm{ml}^{-1}$ clearly increased the lag phase, but did not prevent the growth of $S$. aureus. The combination of both bovicin HC5 and nisin in TSB inhibited the growth of Listeria and S. aureus Embrapa 4018 at lower concentrations than the bacteriocins added separately. Bactericidal effect against L. monocytogenes and S. aureus cells was observed when both bacteriocins were added together in milk in concentrations larger than $400 \mathrm{AU} \mathrm{ml}^{-1}$ of each one. The present results demonstrate that bovicin HC5 and nisin were effective against Listeria and S. aureus assessed in milk, especially when used in combination.
\end{abstract}

Keywords: food pathogen, bovicin HC5, nisin, milk

\section{Introduction}

Outbreaks of listeriosis resulting from consumption of dairy products contaminated with L. monocytogenes have prompted concern about the behavior of this microorganism during processing and subsequent storage of various dairy products (Silva, Almeida, Alves, \& Almeida, 2003). L. monocytogenes, a ubiquitous foodborne pathogen, can be potentially introduced in raw milk in a dairy industry environment. Growth of Listeria in dairy products is often favored by its psychrotrophic nature and tolerance to high salt concentration and relatively low $\mathrm{pH}$ values (Farber \& Peterkin, 1991). L. monocytogenes causes disease in high-risk groups, including pregnant women, neonates, and immunocompromised adults, and has a high mortality rate (Arques, Rodriguez, Nunez, \& Medina, 2008).

Food from animal origins, such as milk, is naturally susceptible to contamination by Staphylococcus aureus, an important pathogen able to grow in a wide range of temperatures, $\mathrm{pH}$ and sodium chloride concentration up $15 \%$, and then able to produce enterotoxins. These toxins are thermostable and maintain their stability even after thermal treatments (Dinges, Orwin, \& Schlievert, 2000; Le Loir, Baron, \& Gautier, 2003).

Although Listeria and S. aureus are inactivated under normal conditions of pasteurization, problems can arise from post-pasteurization contamination, representing a risk to consumers, making necessary an effective control during the steps of food production.

Bacteriocins from lactic acid bacteria are widely studied and have been suggested as a potential biological alternative to improve food safety (Cleveland, Montville, Nes, \& Chikindas, 2001). Nisin is a well known broad spectrum bacteriocin that can inhibit gram-positive bacteria and prevent the outgrowth of spores of Bacilli and Clostridia associated with food (Arques et al., 2004; de Arauz, Jozala, Mazzola, \& Penna, 2009). Although nisin has been widely used in food industries to increase the shelf life of food products, previous studies indicated that many sensitive gram-positive bacteria have developed resistance to nisin (Arques et al., 2008; Zapico, Medina, Gaya, \& Nunez, 1998). 
Bovicin HC5, a bacteriocin produced by Streptococcus bovis HC5, has a broad spectrum of activity (Mantovani, $\mathrm{Hu}$, Worobo, \& Russell, 2002). Previous works demonstrated the ability of bovicin HC5 to inhibit $L$. monocytogenes (Mantovani \& Russell, 2003), and prevent the growth and spore germination of strains of Bacillus cereus and Bacillus thuringiensis (de Carvalho, Costa, Mantovani, \& Vanetti, 2007), Clostridium tyrobutyricum (de Carvalho, Mantovani, \& Vanetti, 2007), and Alicyclobacillus acidoterrestris (de Carvalho, Vanetti, \& Mantovani, 2008). Since bacteria that can readily become resistant to nisin did not become significantly more resistant to bovicin HC5 after they were repeatedly transferred with sublethal doses, it appeared that bovicin HC5 had important characteristics (Mantovani \& Russell, 2003).

Inhibition of L. monocytogenes by bacteriocins such as bovicin HC5; nisin (Boziaris \& Nychas, 2006); curvaticin 13 (Bouttefroy \& Milliere, 2000); cerein 8A (Bizani, Morrissy, Dominguez, \& Brandelli, 2008); reuterin (Arques et al., 2008; El-Ziney \& Jakobsen, 2009); enterocin (Ghrairi, Frere, Berjeaud, \& Manai, 2008) and pediocin AcH (Loessner, Guenther, Steffan, \& Scherer, 2003) demonstrates that this may be a useful strategy for food processing to ensure microbiological safety.

A combination of preservative methods may work synergistically or at least provide greater protection than a single method alone, thus improving the safety and quality of food (Deegan, Cotter, Hill, \& Ross, 2006). Based on this assumption, a combination of bacteriocins has been tested in order to increase antimicrobial activities and improve food safety (Galvez, Abriouel, Lopez, \& Ben Omar, 2007).

The objective of the present work was to study the combined effect of bovicin HC5 and nisin on $L$. monocytogenes, L. innocua and S. aureus in whole milk. Although the effect of nisin combined with other antimicrobial agents has already been extensively studied, this is the first study evaluating the effect of nisin combined with bovicin HC5 on foodborne pathogens.

\section{Materials and Methods}

\subsection{Microorganisms and Growth}

S. bovis HC5 was cultured anaerobically as previously described (Mantovani \& Russell, 2003). Lactococcus lactis ATCC 19435 was cultivated aerobically in de Man, Rogosa and Sharpe (MRS) broth (Merck, Gemany) at $37^{\circ} \mathrm{C}$.

L. monocytogenes ATCC 7644, L. monocytogenes Scott A, L. innocua LMA83 (isolated from a dairy industry), L. innocua LMA84 (isolated from Minas cheese), S. aureus ATCC 25923, S. aureus ATCC 6538 and S. aureus Embrapa 4018 (isolated from bovine mastitis) were cultivated in trypticase soy broth (TSB) (Merck, Germany) and incubated at $37^{\circ} \mathrm{C}$. The identity of all bacterial strains was confirmed by biochemical tests.

\subsection{Preparation and Activity of Bovicin HC5 and Nisin}

Extracts of bovicin HC5 were prepared as described by Mantovani et al. (2002). Bovicin HC5 concentration was estimated by serial two-fold dilutions of extract followed by spotting $25 \mu \mathrm{l}$ on MRS agar using L. lactis ATCC 19435 as the indicator organism. Plates were incubated at $37^{\circ} \mathrm{C}$ for $24 \mathrm{~h}$. One arbitrary unity (AU) was defined as the reciprocal of the highest dilution that showed a zone of inhibition with at least $5 \mathrm{~mm}$ diameter.

Nisin solution (Nisaplin ${ }^{\circledR}$, Danisco, Copenhagen, Denmark) was prepared in phosphate buffer (pH 2.0) and the bacteriocin activity was determined as described earlier.

\subsection{Effect of Bovicin HC5 and, or Nisin on the Growth of Listeria and S. aureus in TSB}

To determine the concentration of bovicin HC5 and nisin (individually or combined) that could inhibit Listeria and $S$. aureus we performed in vitro studies in 96-well microtiter plates. Strains of L. monocytogenes, L. innocua and $S$. aureus were activated in TSB and incubated at $37^{\circ} \mathrm{C}$ for $18 \mathrm{~h}$. The cells were harvested by $3000 \mathrm{~g}$ centrifugation, washed with $0.1 \%$ salt peptone water, and then resuspended in TSB. Listeria and S. aureus cultures $\left(10^{6} \mathrm{CFU} \mathrm{ml}^{-1}\right)$ were treated with bovicin HC5 and nisin at concentration of 10, 50, 100 and $150 \mathrm{AU}$ $\mathrm{ml}^{-1}$ for the tests with isolated bacteriocins. In the assays using bovicin HC5 and nisin combined, the concentrations varied from 10 to $50 \mathrm{AU} \mathrm{ml}^{-1}$.

The bacteria were incubated at $37^{\circ} \mathrm{C}$ and the growth was monitored via changes in optical density at $630 \mathrm{~nm}$ in an ELISA reader (Thermo Plate, model TP-Reader) for up to $10 \mathrm{~h}$ of incubation. Control treatments were performed in TSB inoculated with bacterial cultures without bacteriocins.

\subsection{Effect of Bovicin HC5 and, or Nisin on the Growth of Listeria and S. aureus in Whole Milk}

Cultures of L. monocytogenes Scott A, L. innocua LMA83, and S. aureus ATCC 6538 were selected because they presented more resistant after being treated with bacteriocins in TSB. Cells were activated in $5 \mathrm{ml}$ TSB and incubated at $37^{\circ} \mathrm{C}$ for $18 \mathrm{~h}$, harvested by centrifugation at $3000 \mathrm{~g}$ for $15 \mathrm{~min}$, washed with $0.1 \%$ salt peptone 
water and then, resuspended in $1 \mathrm{ml}$ of ultra-high temperature (UHT) whole milk to reach $10^{7} \mathrm{CFU} \mathrm{ml}^{-1}$. Bovicin HC5 and nisin were added individually $\left(400,800\right.$, and $\left.1200 \mathrm{AU} \mathrm{ml}^{-1}\right)$ or in combination $(400,600$, and $800 \mathrm{AU}$ $\mathrm{ml}^{-1}$ of each bacteriocin).

The tubes were incubated at $37^{\circ} \mathrm{C}$ and samples were taken at $0,3,6,9$, and $12 \mathrm{~h}$ for determination of viable cell number by microdrops (Herbert, 1990) plating aliquots of $25 \mu \mathrm{l}$ in tryptic soy agar (Oxoid, England). Plates were incubated at $37^{\circ} \mathrm{C}$ for 12 or $24 \mathrm{~h}$. Control treatments were performed in milk inoculated with bacterial cultures without bacteriocins.

\subsection{Statistics}

Each experiment was performed at least two times in duplicate. The log of the absorbance and colony forming units was plotted versus time (SigmaPlot version 11.0, USA) and the error bars presented indicate the standard deviation of the mean (shown only in the positive direction).

\section{Results}

3.1 Effect of Bovicin HC5 and/or Nisin on Listeria and S. aureus in TSB

Table 1. Effect of bovicin HC5 or nisin on the growth of Listeria and S. aureus

\begin{tabular}{|c|c|c|c|c|c|}
\hline \multirow[b]{2}{*}{ Microorganism } & \multirow{2}{*}{ 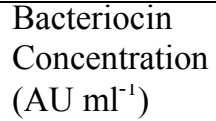 } & \multicolumn{2}{|c|}{$\begin{array}{l}\text { Specific growth rate } \\
\left(\mathrm{h}^{-1}\right)\end{array}$} & \multicolumn{2}{|c|}{$\begin{array}{l}\text { Lag phase duration } \\
\text { (h) }\end{array}$} \\
\hline & & Bovicin HC5 & Nisin & Bovicin HC5 & Nisin \\
\hline \multirow[t]{5}{*}{ L. monocytogenes ATCC 7644} & 0 & 0.60 & 0.60 & 0 & 0 \\
\hline & 10 & 0.26 & - & 0 & $>11$ \\
\hline & 50 & 0.21 & - & 0 & $>11$ \\
\hline & 100 & - & - & $>11$ & $>11$ \\
\hline & 150 & - & - & $>11$ & $>11$ \\
\hline \multirow[t]{5}{*}{ L. monocytogenes Scott A } & 0 & 0.55 & 0.55 & 0,5 & 0 \\
\hline & 10 & 0.32 & - & 0 & 9 \\
\hline & 50 & 0.21 & - & 0 & 10 \\
\hline & 100 & - & - & $>11$ & $>11$ \\
\hline & 150 & - & - & $>11$ & $>11$ \\
\hline \multirow[t]{5}{*}{ L. innocua LMA84 } & 0 & 0.61 & 0.61 & 0 & 0,5 \\
\hline & 10 & - & - & $>11$ & $>11$ \\
\hline & 50 & - & - & $>11$ & $>11$ \\
\hline & 100 & - & - & $>11$ & $>11$ \\
\hline & 150 & - & - & $>11$ & $>11$ \\
\hline \multirow[t]{5}{*}{ L. inпосиа LMA83 } & 0 & 0.59 & 0.59 & 0 & 0 \\
\hline & 10 & 0.30 & 0.84 & 0 & 8 \\
\hline & 50 & 0.28 & - & 0 & $>10$ \\
\hline & 100 & - & - & $>11$ & $>11$ \\
\hline & 150 & - & - & $>11$ & $>11$ \\
\hline \multirow[t]{5}{*}{ S. aureus Embrapa 4018} & 0 & 0.84 & 0.84 & 0 & 0 \\
\hline & 10 & 0.82 & 1.13 & 8 & 8 \\
\hline & 50 & 0.75 & 0.60 & 8 & 8 \\
\hline & 100 & - & - & $>11$ & 10 \\
\hline & 150 & - & - & $>11$ & $>11$ \\
\hline \multirow[t]{5}{*}{ S. aureus ATCC 25923} & 0 & 0.39 & 0.39 & 0 & 0 \\
\hline & 10 & 0.30 & 0.26 & 0 & 2 \\
\hline & 50 & 0.27 & - & 0 & $>11$ \\
\hline & 100 & 0.28 & - & 0 & $>11$ \\
\hline & 150 & 0.28 & - & 0 & $>11$ \\
\hline \multirow[t]{5}{*}{ S. aureus ATCC 6538} & 0 & 0.43 & 0.43 & 0 & 0 \\
\hline & 10 & 0.21 & 0.54 & 1 & 6 \\
\hline & 50 & 0.19 & 0.50 & 1 & 7 \\
\hline & 100 & 0.40 & 0.61 & 8 & 8 \\
\hline & 150 & - & 0.57 & $>11$ & 8 \\
\hline
\end{tabular}

-, no growth; AU, activity units. 
The specific growth rate of L. monocytogenes ATCC 7644 and L. monocytogenes Scott A in TSB was reduced in the presence of bovicin $\mathrm{HC} 5$ at concentrations of 10 and $50 \mathrm{AU} \mathrm{ml}^{-1}$, while growth was completely inhibited in the presence of 100 and $150 \mathrm{AU} \mathrm{ml}^{-1}$ of this bacteriocin (Table 1). L. monocytogenes ATCC 7644 and Scott A were inhibited in TSB even at the smallest nisin concentration of $10 \mathrm{AU} \mathrm{ml}^{-1}$ (Table 1). The effect of the bacteriocins bovicin HC5 and nisin was different on L. innocua: while L. innocua LMA84 was completely inhibited by bovicin $\mathrm{HC} 5$ or nisin at $10 \mathrm{AU} \mathrm{ml}^{-1}$, concentrations up to $50 \mathrm{AU} \mathrm{ml} l^{-1}$ allowed the growth of $L$. innocua LMA83 after a lag phase period (Table 1).

Absorbance reduction of cultures of $L$. monocytogenes and $L$. innocua was observed when both bacteriocins were combined at the concentrations 10 (data not shown) and $50 \mathrm{AU} \mathrm{ml}^{-1}$ (Figure 1), suggesting a bactericidal effect. As the behavior pattern was similar for both strains of $L$. monocytogenes and $L$. innocua, only data from $L$. monocytogenes Scott A and L. innocua LMA83 are shown in Figure 1.

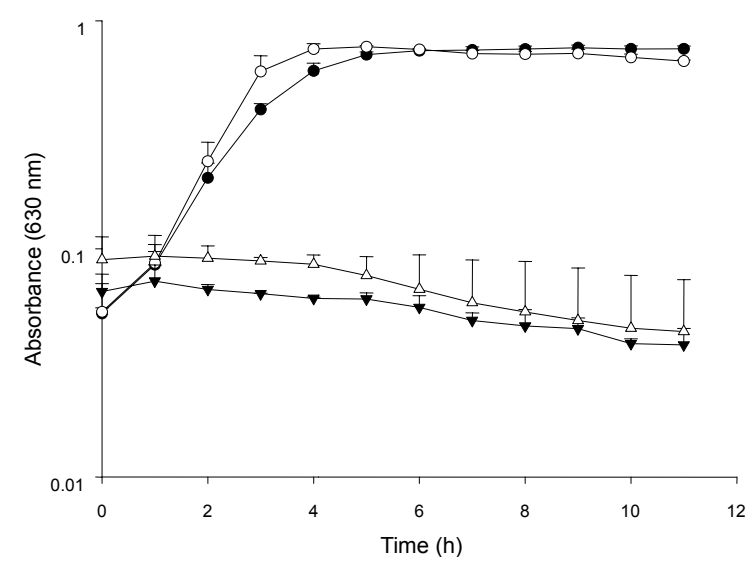

Figure 1. Effect of bovicin HC5 and nisin in combination at $50 \mathrm{AU} \mathrm{ml}^{-1}$ of each one on the growth of $L$. monocytogenes Scott A $(-\boldsymbol{\nabla})$ or $L$. innocua LMA83 $\left(-\Delta^{-}\right)$in TSB. Control without bacteriocins with $L$. monocytogenes Scott A $(-)$ ) or L. innocua LMA83 $(-\odot)$ is also shown

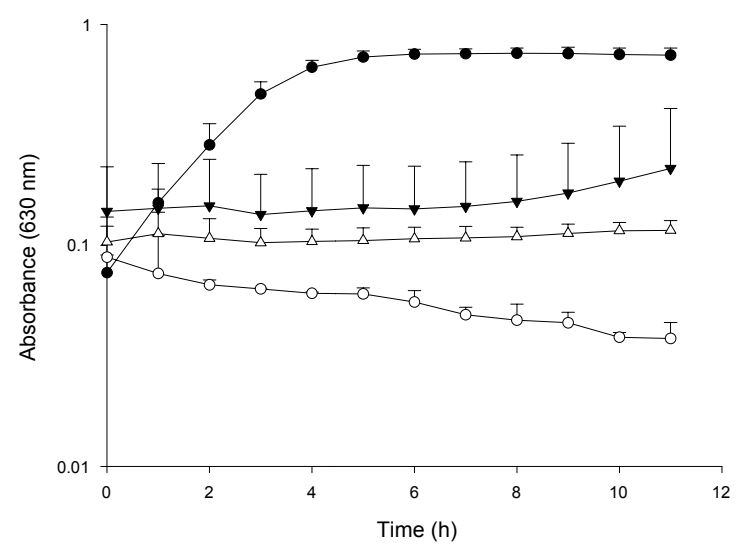

Figure 2. Effect of bovicin HC5 and nisin in combination at $50 \mathrm{AU} \mathrm{ml}^{-1}$ of each one on the growth of $S$. aureus Embrapa $4018\left(-\boldsymbol{O}^{-}\right)$or S. aureus ATCC $25923(\boldsymbol{\nabla})$ or S. aureus ATCC $6538\left(-\Delta^{-}\right)$. Control without bacteriocins with $S$. aureus (-) is also shown

Although the presence of bovicin HC5 or nisin has clearly different impact on the specific growth rate of $S$. aureus Embrapa 4018, ATCC 25923 and ATCC 6538 (Table 1), all three strains were more resistant against the bacteriocins than Listeria. Bovicin HC5 at $150 \mathrm{AU} \mathrm{ml}^{-1}$ was sufficient to inhibit the growth of two of the three $S$. aureus strains tested.

Bovicin HC5 and nisin combined was more effective than the separate bacteriocins to inhibit the growth of $S$. aureus in TSB. Although the addition of bacteriocins in the combined concentration of $10 \mathrm{AU} \mathrm{m}^{-1}$ (data not shown) has reduced the specific growth rate, inhibition was greater when $50 \mathrm{AU} \mathrm{ml}^{-1}$ of each bacteriocin was 
added (Figure 2). The addition of bovicin HC5 and nisin combined at the concentration of $50 \mathrm{AU} \mathrm{ml}^{-1}$, exerted a greater inhibitory effect on S. aureus Embrapa 4018 and ATCC 6538 than the isolated addition of each bacteriocin in the same concentration (Table 1).

\subsection{Effect of Bovicin HC5 and/or Nisin on Listeria and S. aureus in Milk}
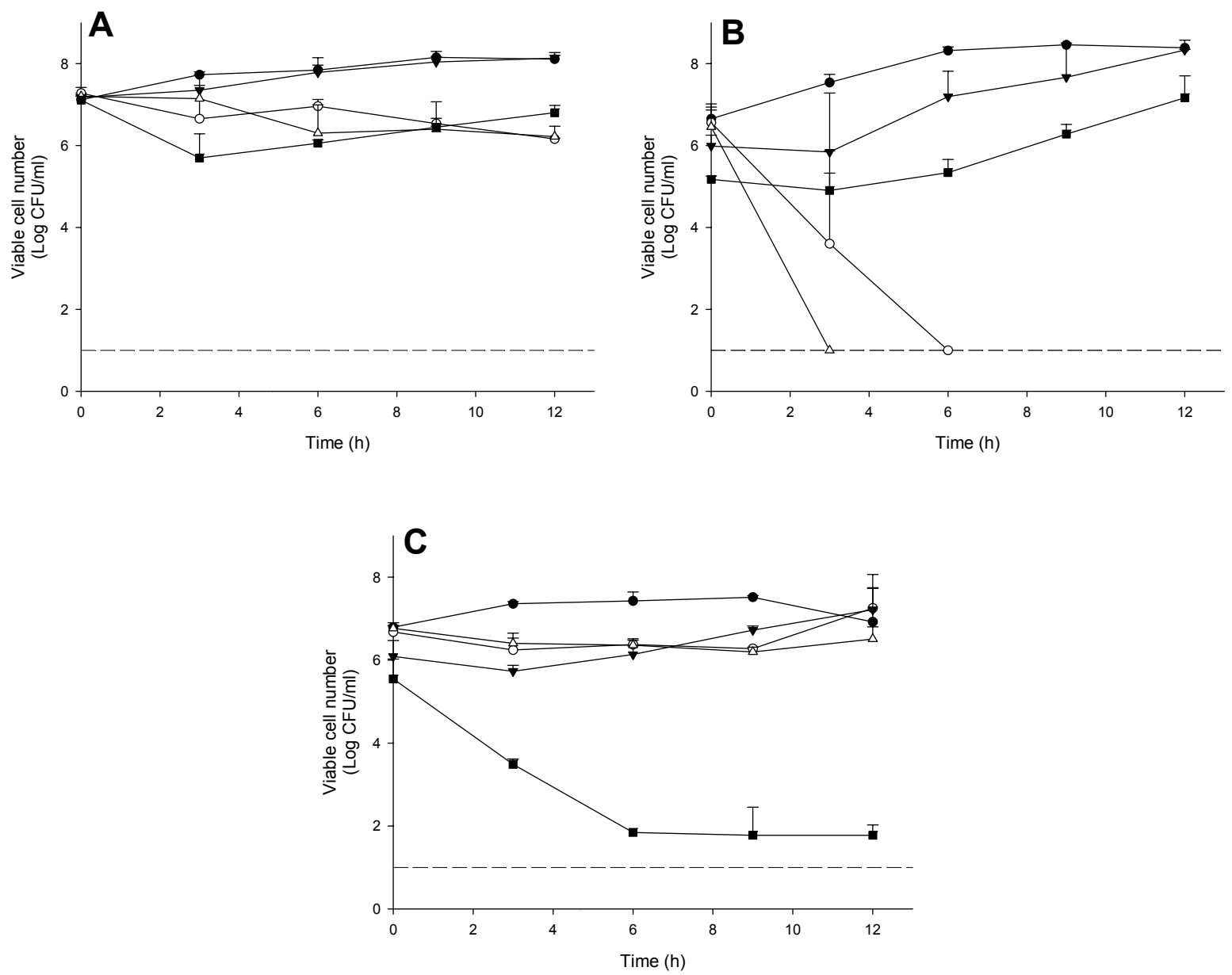

Figure 3. Effect of bovicin HC5 at concentration of $800 \mathrm{AU} \mathrm{ml}^{-1}(-\odot)$ ) and $1200 \mathrm{AU} \mathrm{ml}^{-1}(-\triangle-)$ or nisin at concentration of $800 \mathrm{AU} \mathrm{ml}^{-1}\left(\boldsymbol{\nabla}^{-}\right)$and $1200 \mathrm{AU} \mathrm{ml}^{-1}\left(\boldsymbol{-}^{-}\right)$on the growth of L. monocytogenes Scott A (A). L. innocua LMA83 (B) and S. aureus ATCC 6538 (C) in whole milk. Control without bacteriocins is shown ( $\rightarrow-$ ).

The dotted line shows the detection limit of the enumeration technique used

L. monocytogenes Scott A, L. innocua LMA83 and S. aureus ATCC 6538 strains were selected to evaluate the effect of bacteriocins in milk. The addition of bovicin HC5 at 400 (data not shown), 800 and $1200 \mathrm{AU} \mathrm{ml}^{-1}$ to milk reduced the viable cell number of L. monocytogenes (Figure 3A). Although a pronounced effect was observed when $1200 \mathrm{AU} \mathrm{ml}^{-1}$ of nisin was used, the growth was resumed after $3 \mathrm{~h}$ of incubation (Figure 3A). The lethal effect of nisin and bovicin HC5 combined on L. monocytogenes in whole milk was observed at concentrations of 600 and $800 \mathrm{AU} \mathrm{ml}^{-1}$ of each, with a sharp reduction in the cell number to below the detection limit of the technique, which is $10^{1} \mathrm{CFU} \mathrm{ml}^{-1}$ (Figure $4 \mathrm{~A}$ ). 

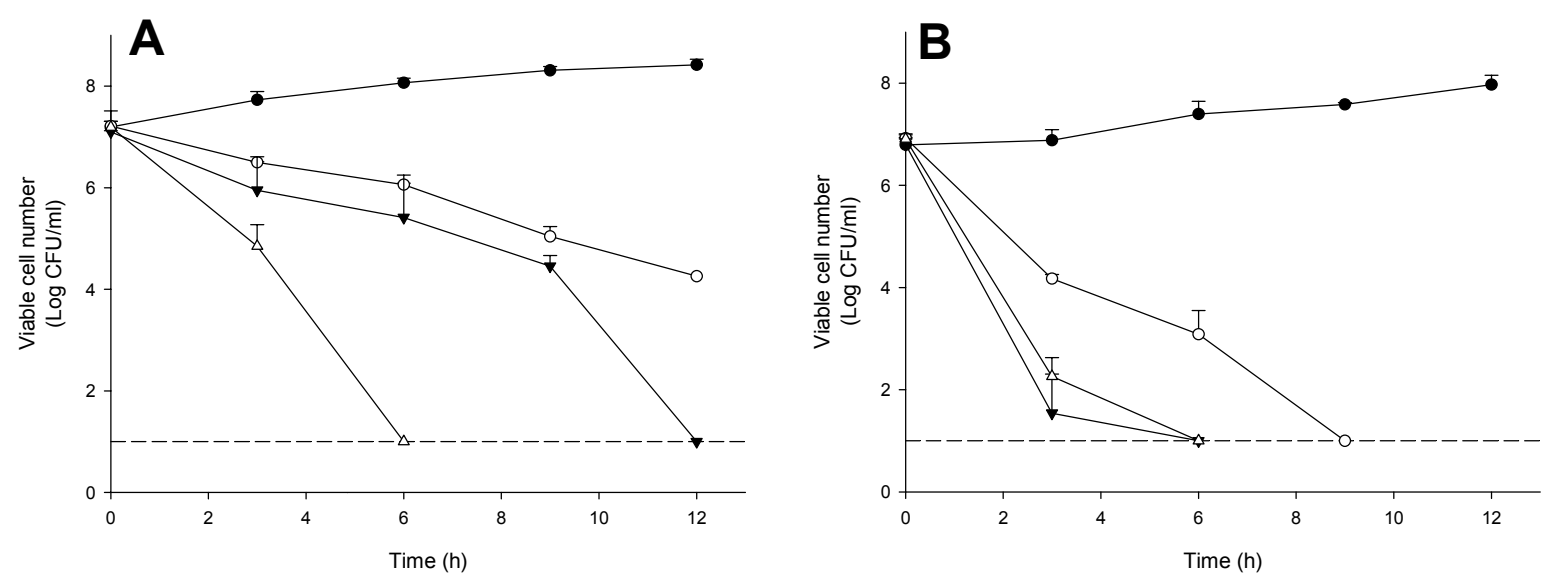

Figure 4. Effect of the combination of bovicin HC5 and nisin at $400 \mathrm{AU} \mathrm{ml}^{-1}\left(-{ }^{-}\right), 600 \mathrm{AU} \mathrm{ml}^{-1}(-\boldsymbol{\nabla}$ ) ) or 800 $\mathrm{AU} \mathrm{ml} l^{-1}(-\triangle)$ of each one on the growth of L. monocvtogenes Scott A (A) and S. aureus ATCC 6538 (B) in whole milk. Control without bacteriocins is shown $(\rightarrow-)$. The dotted line shows the detection limit of the enumeration technique used

Bovicin HC5 concentrations from 400 to $1200 \mathrm{AU} \mathrm{ml}^{-1}$ in milk were also bactericidal to L. innocua and the viable cell number was reduced by more than $5 \log$ cycles. Although nisin has exerted an inhibitory effect on $L$. innocua by increasing $3 \mathrm{~h}$ in the lag phase, the growth was resumed after this period (Figure 3B).

The major resistance of $S$. aureus to the bacteriocins effect observed in TSB was confirmed in milk and the concentration of $800 \mathrm{AU} \mathrm{ml}^{-1}$ did not prevent the growth of S. aureus ATCC 6538 (Figure 3C). At the highest concentration (1200 AU ml ${ }^{-1}$ ), bovicin HC5 exerted a bacteriostatic effect while nisin initially exerted a bactericidal effect during $6 \mathrm{~h}$ after exposition followed by a bacteriostatic effect (Figure 3C). However, the combination of bovicin HC5 and nisin reduced the viable cell number of $S$. aureus ATCC 6538 in UHT milk to below the detection limit of the technique, within $9 \mathrm{~h}$ of incubation (Figure 4B).

\section{Discussion}

Bacteriocins have been used as a food preservative, mainly against foodborne pathogens. However, our finding that Listeria and S. aureus growth can be resumed after the lag phase indicates selection of resistant bacteria to bacteriocins and this is a problem to be addressed before the adoption of a food preservation process. Another study also found a transient antimicrobial effect of $100 \mathrm{AU} \mathrm{ml}^{-1}$ of nisin or $320 \mathrm{AU} \mathrm{ml}^{-1}$ of curvaticin 13, a bacteriocin produced by Lactobacillus curvatus SB13, against L. monocytogenes ATCC 7644 being the growth resumed after approximately $9 \mathrm{~h}$ of incubation at $37^{\circ} \mathrm{C}$ (Bouttefroy \& Milliere, 2000). L. monocytogenes resistant to antimicrobial agents showed an increase in the proportion of saturated fatty acids that can increase the rigidity of the cell membrane, making it less fluid and thus preventing the penetration of molecules of bacteriocins (Naghmouchi, Belguesmia, Baah, Teather, \& Drider, 2011; Naghmouchi, Kheadr, Lacroix, \& Fliss, 2007). The resistance of some species of Staphylococcus to nisin is associated with increased amounts of D-alanine in the structure of teichoic acids present in the peptidoglycan layer of these bacteria becoming the cells more positively charged (Peschel et al., 1999). These changes may hinder the interaction of nisin, positively charged, with the surface of cells.

The antimicrobial activity of nisin is related to its abilities to bind specifically to lipid II, a precursor in the biosynthesis of cell wall, and to form pores leading to cell death due to loss of intracellular compounds (Breukink \& de Kruijff, 2006; Breukink et al., 2003). As a lantibiotic, bovicin HC5 has a primary mode of action similar to nisin, which involves specific interaction with lipid II. However, some differences regarding the pore-forming capacity of both bacteriocins were observed in model membranes: the pore-formation by bovicin HC 5 was clearly dependent on membrane thickness, being observed only in thinner membranes (Paiva, Breukink, \& Mantovani, 2011). Independent on the pore formation, bovicin HC5 maintains its antibacterial activity by recruiting lipid II molecules in a prepore-like structure, and consequently preventing the use of such molecules in the cell wall synthesis (Paiva et al., 2011). 
Another issue to consider is the variation of resistance to bacteriocins found among strains of the same species. For example, we noted that bovicin HC5 and nisin have exerted an inhibitory effect on L. monocytogenes but strain ATCC 7644 was more sensitive to nisin while L. monocytogenes Scott A was more sensitive to bovicin HC5. The sensitivity variation to nisin among different strains of $S$. aureus isolated from dairy products was also observed (Sudagidan \& Yemenicioglu, 2012). Mantovani and Russell (2003) found that some bacteria resistant to nisin showed no significant resistance to bovicin HC5, even after repeated treatments with sublethal doses of that bacteriocin. Higher concentrations of bacteriocins could increase the bactericidal effect and reduce the chances of selecting resistant bacteria and to have an inhibitory effect on several strains that could contaminate food.

Another alternative to reduce the selection of resistant cells would be the combined use of bacteriocins. In this study we showed that the impact of bovicin $\mathrm{HC} 5$ and nisin can be greatly enhanced if both bacteriocins are applied in combination. In fact, concentrations as low as $10 \mathrm{AU} \mathrm{ml}^{-1}$ of each bacteriocin in TSB resulted in reduction of the absorbance of cultures of $L$. monocytogenes Scott A and L. innocua LMA83 indicating cell lysis. The results showed that the combined effect of bovicin HC5 and nisin allow the use of lower dosages compared to the individual application.

According to Gálvez et al. (2007) when cells are exposed to a combination of antimicrobial factors, the intensity of the damage can be increased since these factors may act on different sites of the same target. The repair of multiple damages may require a high energy expenditure, resulting in energy depletion and cell death. The addition of nisin $(0.5 \% \mathrm{w} / \mathrm{v})$ in ready to eat salad did not achieved the complete inactivation of L. monocytogenes but the combination of this bacteriocin with enterocin AS-48 reduced the concentration of viable cells below the detection limit of the technique after $24 \mathrm{~h}$ of incubation (Molinos et al., 2009).

Although the addition of bacteriocins in milk used for consumption is not permitted, this product serves as an important system to evaluate the influence of chemical composition of milk on the activity of bacteriocins. Milk is a complex mixture of substances such as water, protein, lactose and fat, which can affect the effectiveness of bacteriocins. The addition of nisin at concentrations of $62.5,125,250$ and $500 \mathrm{IU} \mathrm{ml}^{-1}$ in skim milk had a significant effect on L. monocytogenes, while in raw milk, the inhibitory activity was only moderate, with a rapid reduction of the L. monocytogenes population during two days of incubation before growth was resumed (Kim, Choi, Bajpai, \& Kang, 2008). These results demonstrate that the activity of bacteriocin is dependent on the fat content in milk, and the interaction between the lipids of milk and nisin may limit the application of this bacteriocin in dairy fat products (Sobrino-Lopez \& Martin-Belloso, 2008).

No research to assess the synergistic effect of bovicin HC5 with another antimicrobial agent in milk was carried out so far. However, results from the synergistic effect of nisin and other antimicrobial substances can be exemplified. Nisin combined with garlic extract showed potential antilisterial activity with a synergistic effect in reducing the viable cell number of $L$. monocytogenes in milk and skim milk in 14 days (Kim et al., 2008). Synergistic effect was also found by Arqués et al. (2008) evaluating the combination of nisin and reuterin, antimicrobial produced by Lactobacillus reuteri, in milk. These authors reported a reduction of approximately two $\log$ cycles of $S$. aureus treated with these antimicrobials in combination after $24 \mathrm{~h}$ of incubation.

\section{Conclusions}

The present study demonstrates that the combination of bovicin HC5 and nisin against Listeria and S. aureus in TSB and milk was more effective than the addition of these bacteriocins individually. These results indicate their potential use as biopreservatives in food. However, the molecular basis of synergistic effect between bovicin HC5 and nisin are now under investigation. Furthermore, the combination of bovicin HC5 with others antimicrobial agents against foodborne pathogens is focus of further research.

\section{Aknowledgments}

N. J. Pimentel-Filho was supported by a fellowship from Conselho Nacional de Desenvolvimento Científico e Tecnológico $(\mathrm{CNPq})$ and this research has been supported by Fundação de Amparo à Pesquisa do Estado de Minas Gerais (FAPEMIG), Brazil.

\section{References}

Arques, J. L., Fernandez, J., Gaya, P., Nunez, M., Rodriguez, E., \& Medina, M. (2004). Antimicrobial activity of reuterin in combination with nisin against food-borne pathogens. Int J Food Microbiol, 95(2), 225-229. http://dx.doi.org/10.1016/j.ijfoodmicro.2004.03.009

Arques, J. L., Rodriguez, E., Nunez, M., \& Medina, M. (2008). Antimicrobial activity of nisin, reuterin, and the lactoperoxidase system on Listeria monocytogenes and Staphylococcus aureus in cuajada, a semisolid dairy product manufactured in Spain. J Dairy Sci, 91(1), 70-75. http://dx.doi.org/10.3168/jds.2007-0133 
Bizani, D., Morrissy, J. A., Dominguez, A. P., \& Brandelli, A. (2008). Inhibition of Listeria monocytogenes in dairy products using the bacteriocin-like peptide cerein 8A. Int J Food Microbiol, 121(2), $229-233$. http://dx.doi.org/10.1016/j.ijfoodmicro.2007.11.016

Bouttefroy, A., \& Milliere, J. B. (2000). Nisin-curvaticin 13 combinations for avoiding the regrowth of bacteriocin resistant cells of Listeria monocytogenes ATCC 15313. Int J Food Microbiol, 62(1-2), 65-75. http://dx.doi.org/10.1016/S0168-1605(00)00372-X

Boziaris, I. S., \& Nychas, G. J. (2006). Effect of nisin on growth boundaries of Listeria monocytogenes Scott A, at various temperatures, $\mathrm{pH}$ and water activities. Food Microbiol, 23(8), 779-784. http://dx.doi.org/10.1016/j.fm.2006.03.003

Breukink, E., \& de Kruijff, B. (2006). Lipid II as a target for antibiotics. Nat Rev Drug Discov, 5(4), $321-332$. http://dx.doi.org/10.1038/nrd2004

Breukink, E., van Heusden, H. E., Vollmerhaus, P. J., Swiezewska, E., Brunner, L., Walker, S., . . de Kruijff, B. (2003). Lipid II is an intrinsic component of the pore induced by nisin in bacterial membranes. J Biol Chem, 278(22), 19898-19903. http://dx.doi.org/10.1074/jbc.M301463200

Cleveland, J., Montville, T. J., Nes, I. F., \& Chikindas, M. L. (2001). Bacteriocins: safe, natural antimicrobials for food preservation. Int J Food Microbiol, 71(1), 1-20. http://dx.doi.org/10.1074/jbc.M301463200

de Arauz, L. J., Jozala, A. F., Mazzola, P. G., \& Penna, T. C. V. (2009). Nisin biotechnological production and application: a review. Trends in Food Science \& Technology, 20(3-4), 146-154. http://dx.doi.org/10.1016/j.tifs.2009.01.056

de Carvalho, A. A., Costa, E. D., Mantovani, H. C., \& Vanetti, M. C. (2007). Effect of bovicin HC5 on growth and spore germination of Bacillus cereus and Bacillus thuringiensis isolated from spoiled mango pulp. Journal of Applied Microbiology, 102(4), 1000-1009. http://dx.doi.org/10.1016/j.tifs.2009.01.056

de Carvalho, A. A., Mantovani, H. C., \& Vanetti, M. C. (2007). Bactericidal effect of bovicin HC5 and nisin against Clostridium tyrobutyricum isolated from spoiled mango pulp. Letters in Applied Microbiology, 45(1), 68-74. http://dx.doi.org/10.1111/j.1472-765X.2007.02150.x

de Carvalho, A. A., Vanetti, M. C., \& Mantovani, H. C. (2008). Bovicin HC5 reduces thermal resistance of Alicyclobacillus acidoterrestris in acidic mango pulp. Journal of Applied Microbiology, 104(6), 1685-1691. http://dx.doi.org/10.1111/j.1365-2672.2007.03710.x

Deegan, L. H., Cotter, P. D., Hill, C., \& Ross, P. (2006). Bacterlocins: Biological tools for bio-preservation and shelf-life extension. International Dairy Journal, 16(9), 1058-1071. http://dx.doi.org/10.1016/j.idairyj.2005.10.026

Dinges, M. M., Orwin, P. M., \& Schlievert, P. M. (2000). Exotoxins of Staphylococcus aureus. Clin Microbiol Rev, 13(1), 16-34, table of contents. http://dx.doi.org/10.1128/CMR.13.1.16-34.2000

El-Ziney, M. G., \& Jakobsen, M. (2009). Effectiveness of reuterin alone and in combination with nisin or other food contact surfaces sanitizers and cleaners for disinfection of stainless steel surfaces contaminated with Escherichia coli and Listeria innocua. Journal of Food Agriculture \& Environment, 7(3-4), 145-149.

Farber, J. M., \& Peterkin, P. I. (1991). Listeria-Monocytogenes, a Food-Borne Pathogen. Microbiological Reviews, 55(3), 476-511.

Galvez, A., Abriouel, H., Lopez, R. L., \& Ben Omar, N. (2007). Bacteriocin-based strategies for food biopreservation. Int J Food Microbiol, 120(1-2), 51-70. http://dx.doi.org/10.1016/j.ijfoodmicro.2007.06.001

Ghrairi, T., Frere, J., Berjeaud, J. M., \& Manai, M. (2008). Purification and characterisation of bacteriocins produced by Enterococcus faecium from Tunisian rigouta cheese. Food Control, 19(2), 162-169. http://dx.doi.org/10.1016/j.foodcont.2007.03.003

Herbert, R. A. (1990). Methods for Enumerating Microorganisms and Determining Biomass in Natural Environments. Methods in Microbiology, 22, 1-39. http://dx.doi.org/10.1016/S0580-9517(08)70238-1

Kim, E. L., Choi, N. H., Bajpai, V. K., \& Kang, S. C. (2008). Synergistic effect of nisin and garlic shoot juice against Listeria monocytogenes in milk. Food Chemistry, 110(2), 375-382. http://dx.doi.org/10.1016/j.foodchem.2008.02.013

Le Loir, Y., Baron, F., \& Gautier, M. (2003). Staphylococcus aureus and food poisoning. Genet Mol Res, 2(1), 63-76. 
Loessner, M., Guenther, S., Steffan, S., \& Scherer, S. (2003). A pediocin-producing Lactobacillus plantarum strain inhibits Listeria monocytogenes in a multispecies cheese surface microbial ripening consortium. Applied and Environmental Microbiology, 69(3), 1854-1857. http://dx.doi.org/10.1128/AEM.69.3.1854-1857.2003

Mantovani, H. C., Hu, H., Worobo, R. W., \& Russell, J. B. (2002). Bovicin HC5, a bacteriocin from Streptococcus bovis HC5. Microbiology, 148(Pt 11), 3347-3352.

Mantovani, H. C., \& Russell, J. B. (2003). Inhibition of Listeria monocytogenes by bovicin HC5, a bacteriocin produced by Streptococcus bovis HC5. Int J Food Microbiol, 89(1), 77-83.

Molinos, A. C., Abriouel, H., Lopez, R. L., Ben Omar, N., Valdivia, E., \& Galvez, A. (2009). Enhanced bactericidal activity of enterocin AS-48 in combination with essential oils, natural bioactive compounds and chemical preservatives against Listeria monocytogenes in ready-to-eat salad. Food and Chemical Toxicology, 47(9), 2216-2223. http://dx.doi.org/10.1016/j.fct.2009.06.012

Naghmouchi, K., Belguesmia, Y., Baah, J., Teather, R., \& Drider, D. (2011). Antibacterial activity of class I and IIa bacteriocins combined with polymyxin E against resistant variants of Listeria monocytogenes and Escherichia coli. Res Microbiol, 162(2), 99-107. http://dx.doi.org/10.1016/j.resmic.2010.09.014

Naghmouchi, K., Kheadr, E., Lacroix, C., \& Fliss, I. (2007). Class I/Class IIa bacteriocin cross-resistance phenomenon in Listeria monocytogenes. Food Microbiol, 24(7-8), 718-727. http://dx.doi.org/10.1016/j.fm.2007.03.012

Paiva, A. D., Breukink, E., \& Mantovani, H. C. (2011). Role of lipid II and membrane thickness in the mechanism of action of the lantibiotic bovicin HC5. Antimicrob Agents Chemother, 55(11), 5284-5293. http://dx.doi.org/10.1128/AAC.00638-11

Peschel, A., Otto, M., Jack, R. W., Kalbacher, H., Jung, G., \& Gotz, F. (1999). Inactivation of the dlt operon in Staphylococcus aureus confers sensitivity to defensins, protegrins, and other antimicrobial peptides. $J$ Biol Chem, 274(13), 8405-8410. http://dx.doi.org/10.1074/jbc.274.13.8405

Silva, I. M., Almeida, R. C., Alves, M. A., \& Almeida, P. F. (2003). Occurrence of Listeria spp. in critical control points and the environment of Minas Frescal cheese processing. Int J Food Microbiol, 81(3), 241-248. http://dx.doi.org/10.1016/S0168-1605(02)00223-4

Sobrino-Lopez, A., \& Martin-Belloso, O. (2008). Enhancing the lethal effect of high-intensity pulsed electric field in milk by antimicrobial compounds as combined hurdles. J Dairy Sci, 91(5), 1759-1768. http://dx.doi.org/10.3168/jds.2007-0979

Sudagidan, M., \& Yemenicioglu, A. (2012). Effects of nisin and lysozyme on growth inhibition and biofilm formation capacity of Staphylococcus aureus strains isolated from raw milk and cheese samples. J Food Prot, 75(9), 1627-1633. http://dx.doi.org/10.4315/0362-028X.JFP-12-001

Zapico, P., Medina, M., Gaya, P., \& Nunez, M. (1998). Synergistic effect of nisin and the lactoperoxidase system on Listeria monocytogenes in skim milk. International Journal of Food Microbiology, 40(1-2), 35-42. http://dx.doi.org/10.1016/S0168-1605(98)00008-7

\section{Copyrights}

Copyright for this article is retained by the author(s), with first publication rights granted to the journal.

This is an open-access article distributed under the terms and conditions of the Creative Commons Attribution license (http://creativecommons.org/licenses/by/3.0/). 